\title{
Optimization of lipase-catalyzed synthesis of palm amino acid surfactant using response surface methodology (RSM).
}

\begin{abstract}
Aminoacid surfactants are high-value surfactants which have excellent emulsifying characteristics and minimal toxicity to the living body. Enzymatic synthesis of palm kernel aminoacid surfactant was optimized by response surfacemethodology (RSM) using palm kernel olein (PKO) and 1(+)-lysine catalyzed by Lipozyme RM IM. The reaction was performed in batch mode stirred tank reactor (STR) with one multi-bladed impeller. A central composite rotatable design (CCRD) was employed to evaluate the interactive effects of various parameters. The parameters were temperature $(\mathrm{A}):\left(40.00-70.00{ }^{\circ} \mathrm{C}\right)$, impeller speed (B): (100.00-400.00 rpm), substrates ratio (C): (1.00-4.00 mmol) and enzyme amount (D): (5.00-8.00 g). The optimum condition derived via RSM at fixed reaction time of $24 \mathrm{~h}$ was temperature; $47.50{ }^{\circ} \mathrm{C}$, impeller speed; $323.96 \mathrm{rpm}$, substrates ratio; $3.25 \mathrm{mmol}$ and enzyme amount; $7.25 \mathrm{~g}$. The experimental yield was $89.03 \%$ under the optimum condition, which compared well with the maximum predicted value of $93.77 \%$.
\end{abstract}

Keyword: Aminoacid surfactants; Palm kernel olein (PKO); Lipozyme; Stirred tank reactor (STR); Central composite rotatable design (CCRD). 